\title{
Triphenylamine-Merocyanine-Based D1-A1- $\pi$-A2/A3-D2 Chromophore System: Synthesis, Optoelectronic, and Theoretical Studies
}

\author{
Pedada Srinivasa Rao ${ }^{1,2}$, Avinash L. Puyad ${ }^{3}$, Sidhanath V. Bhosale ${ }^{1,2, *}$ and \\ Sheshanath V. Bhosale ${ }^{4, *(\mathbb{D}}$ \\ 1 Polymers and Functional Materials Division, CSIR-Indian Institute of Chemical Technology, \\ Hyderabad 500007, India; srinuchem99@gmail.com \\ 2 Academy of Scientific and Innovative Research (AcSIR), Ghaziabad 201002, India \\ 3 School of Chemical Sciences, Swami Ramanand Teerth Marathwada University, Nanded 431606, India; \\ avinashlpuyad@gmail.com \\ 4 Department of Chemistry, Goa University, Taleigao Plateau, Goa 403206, India \\ * Correspondence: sidhanath.bhosale@gmail.com (S.V.B.); svbhosale@unigoa.ac.in (S.V.B.)
}

Received: 26 February 2019; Accepted: 29 March 2019; Published: 1 April 2019

\begin{abstract}
Donor-acceptor- $\pi$-acceptor-donor (D1-A1- $\pi$-A2/A3-D2)-type small molecules, such TPA-MC-2 and TPA-MC-3, were designed and synthesized starting from donor-substituted alkynes (TPA-MC-1) via [2 + 2] cycloaddition-retroelectrocyclization reaction with tetracyanoethylene (TCNE) and 7,7,8,8-tetracyanoquinodimethane (TCNQ) units, respectively. TPA-MC-2 and TPA-MC-3 chromophores differ on the A2/A3 acceptor subunit, which is 1,1,4,4-tetracyanobutadiene (TCBD) and a dicyanoquinodicyanomethane (DCQDCM), respectively. Both the derivative bearing same donors D1 (triphenylamine) and D2 (trimethylindolinm) and also same A1 (monocyano) as an acceptor, tetracyano with an aryl rings as the $\pi$-bridging moiety. The incorporation of TCNE and TCNQ as strong electron withdrawing units led to strong intramolecular charge-transfer (ICT) interactions, resulting in lower LUMO energy levels. Comparative UV-Vis absorption, fluorescence emission, and electrochemical and computational studies were performed to understand the effects of the TCNE and TCNQ subunits incorporated on TPA-MC-2 and TPA-MC-3, respectively.
\end{abstract}

Keywords: donor-acceptor; cyclic voltammograms; triphenylamine; tetracyanoethylene; 7,7,8,8-tetracyanoquinodimethane

\section{Introduction}

The fabrication of low-cost electronic devices such as bulk heterojunction (BHJ) and organic solar cells (OSCs) has become important in commercial applications because of their light-absorbing characteristics. Therefore, the band gap engineering of such chromophores aims to improve the efficiency of the devices through the manipulation of highest occupied molecular orbitals (HOMO) and lowest unoccupied molecular orbitals (LUMO), thus, has attracted wide attention of researchers [1,2]. From literature study it is clear that OSCs will lead to build promising next generation clean and renewable energy devices [3]. The optoelectronic properties of chromophore could be altered by varying the strength of donor (D) or acceptor (A) subunits [4-10]. To achieve this researcher employed the cross-conjugation reaction to tune the LUMO energy level of chromophores [11-15]. To fulfill this requirement, [2 + 2] cycloaddition-retroelectrocyclization reaction of electron withdrawing moieties such as tetracyanoethene (TCNE) and 7,7,8,8-tetracyanoquinodimethane (TCNQ) with $\pi$-conjugated system comprised of activated alkynes were used [11,16-22]. Nevertheless, the chromophores bearing 
TCBD and dicyanoquinodicyanomethane (DCQDCM) in backbone display low LUMO, which is necessary to improve the OSCs device performance because strong intramolecular charge-transfer (ICT) interaction observed in D and TCNQ and DCQDCM acceptors [11,12]. The literature search revealed that TCBD and DCQDCM incorporated D-A chromophores and polymers were employed to fabricate the nonlinear, molecular batteries, and also optoelectronic materials [10,22-25].

Merocyanine (MC) dyes are the traditional colorant exhibits high absorption coefficient, tunable absorption properties and applied as textile colorant. They are attractive dyes for high technological applications such as nonlinear optics and photorefractive materials due to their polarizabilities and dipole moments [26-29]. Merocyanine dyes are also promising candidates for dye-sensitized solar cells (DSSCs) [30-35], photorefractive applications [36-38], and solution-processed BHJ OSCs [39,40]. Würthner and coworkers extensively investigated bulk heterojunction (BHJ) OSCs application of merocyanine dyes [41-43].

On the other hand, triphenylamine (TPA) has been recognized as a very promising electron-donor unit due to its charge transport characteristics [44-49]. TPA and its derivatives were used in various fields such as electrochromism, organic electronics, two-photon absorption, DSSCs, and organic photovoltaics [50-55].

Considering the above properties of MC and TPA, herein, we report synthesis of two chromophores, TPA-MC-2 and TPA-MC-3, prepared by the Sonogashira-Hagihara coupling reaction followed by [2 + 2] cycloaddition-retroelectrocyclization click chemistry reaction [56]. The thermal, absorption, photoluminescence, electrochemical, and theoretical studies of these derivatives were investigated in detail. Furthermore, we also examined the effect of enhanced $\pi$-conjugation on these properties to find out energy band gaps.

\section{Results and Discussion}

\subsection{Design}

We designed and synthesized small molecule conjugates D1-A1- $\pi$-A2/A3-D2 composed of electron donor and acceptor moieties. Here we presume that the designed molecule D1-A1- $\pi$-A2/A3-D2 will display broad range absorption and electron accepting characteristics, thus, such a design strategy comprising alternate donor-acceptor subunits is useful to improve the photovoltaic performance and could reduce the energy band gap [57-59]. The designed D1-A1- $\pi-A 2-D 2$ systems are rarely explored, which is made up of four different subunits, i.e., the MC donor unit at one terminal end and the TPA donor subunit at another end, and both the donor moieties are covalently linked at center with two different acceptor subunits, such as - $\mathrm{CN}$ and either of TCBD or DCQDCM chromophore via an aromatic $\pi$-system, respectively.

\subsection{Synthesis and Characterization}

The synthesis of the designed target molecules TPA-MC-2 and TPA-MC-3 is shown in Scheme 1 and synthesis of starting material TPA-MC-1 as shown is Scheme 2. The intermediate 4-ethynyl-N,N-diphenylaniline 3 was synthesized from triphenylamine in three steps as shown in Scheme 2 [60], whereas (2E,4E)-2-(4-iodophenyl)-4-(1,3,3-trimethylindolin-2-ylidene)but-2-enenitrile 6 was prepared from 4-iodo phenyl acetonitrile 4 and 2-(1,3,3-trimethylindolin-2-ylidene) acetaldehyde 5 via Knoevenagel condensation reaction [61]. The Sonogashira-Hagihara coupling method was used to prepare starting TPA-MC-1 derivative from compound 3 and 6 [62-64]. The obtained TPA-MC-1 was further subject to react with TCNE and TCNQ through [2+2] cycloaddition-retroelectrocyclization click chemistry to yield TPA-MC-2 and TPA-MC-3, respectively (Scheme 1). The chemical structures of TPA-MC-1, TPA-MC-2, and TPA-MC-3 were confirmed by modern spectroscopic techniques, such as FT-IR, ${ }^{1} \mathrm{H}$ NMR, ${ }^{13} \mathrm{C}$ NMR spectroscopy, and mass and high-resolution mass spectrometry (HRMS) (Figures S8-S29). 


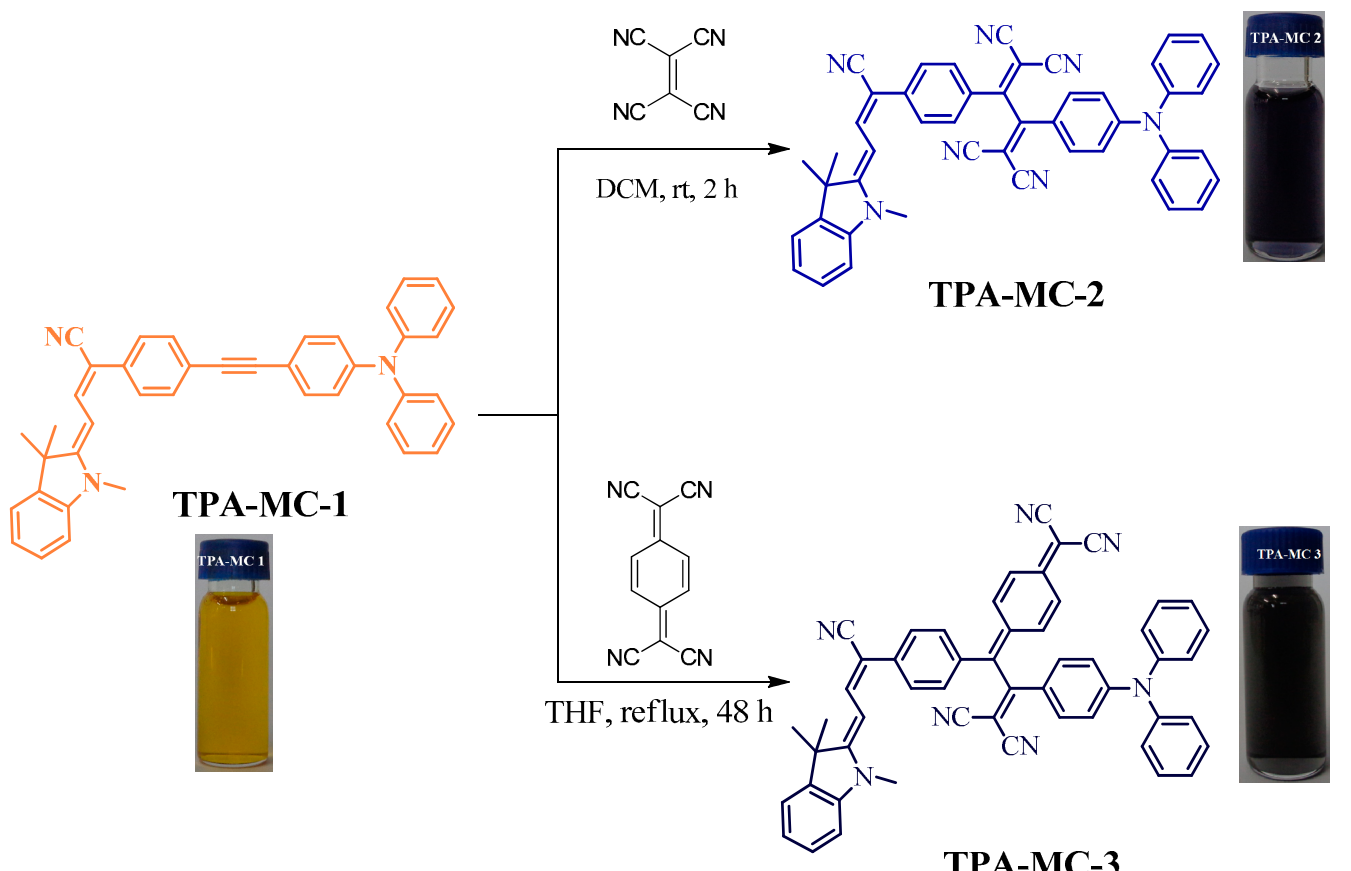

Scheme 1. Synthesis of target donor-acceptordonor-acceptor- $\pi$-acceptor-donor systems.

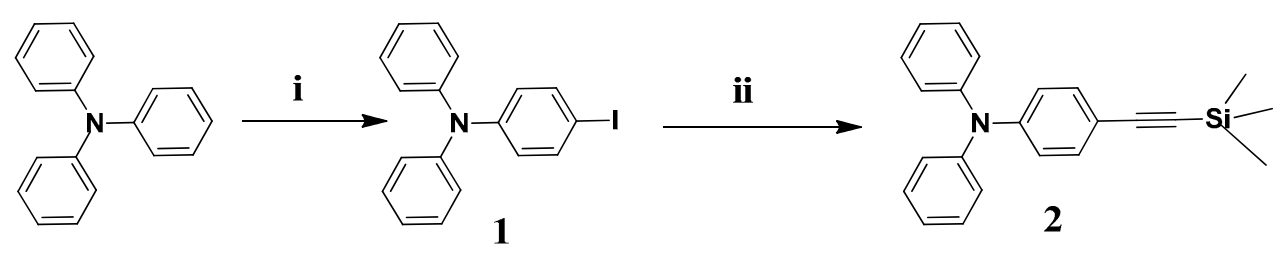

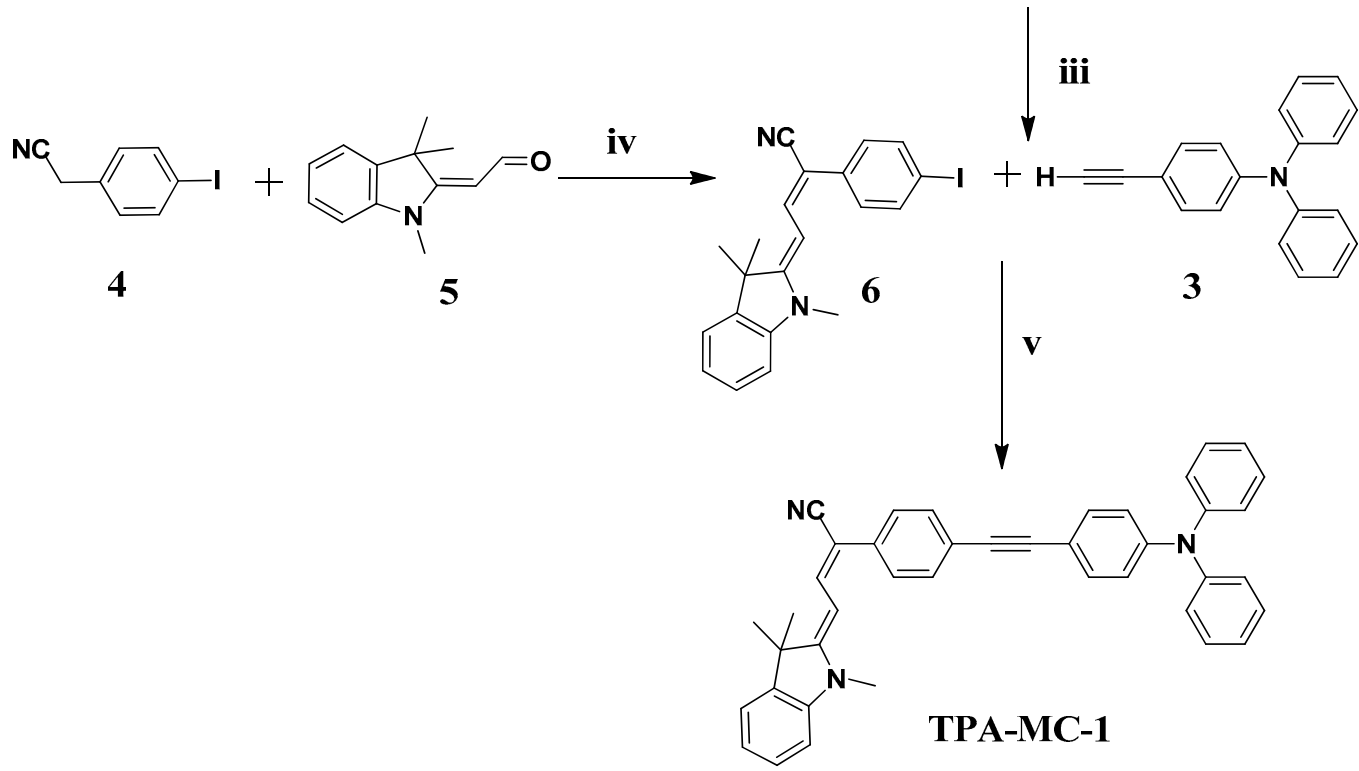

Scheme 2. Reagents and conditions: (i) NIS, $\mathrm{CHCl}_{3}+\mathrm{CH}_{3} \mathrm{COOH}(1: 1), \mathrm{rt}, 12 \mathrm{~h}$; (ii) $\mathrm{PdCl}_{2}\left(\mathrm{PPh}_{3}\right)_{2} / \mathrm{CuI}$, $\mathrm{Et}_{3} \mathrm{~N}$, dry THF, TMSA, rt, $12 \mathrm{~h}$; (iii) $\mathrm{K}_{2} \mathrm{CO}_{3}, \mathrm{MeOH}+\mathrm{THF}(1: 1), \mathrm{rt}, 4 \mathrm{~h}$; (iv) piperidine, dry THF, $12 \mathrm{~h}$; and (v) $\mathrm{Pd}\left(\mathrm{PPh}_{3}\right)_{4} / \mathrm{CuI}$, DIPEA, dry THF, reflux, $12 \mathrm{~h}$.

The thermal stability of the three synthesized compounds-TPA-MC-1, TPA-MC-2 and TPA-MC-3-were determined using thermogravimetric analysis (TGA) (Figures S1-S3). The samples were heated up to $600{ }^{\circ} \mathrm{C}$ at a rate of $10^{\circ} \mathrm{C} / \mathrm{min}$ under nitrogen atmosphere. TPA-MC- 1 exhibits the wt. loss of $5 \%$ at $331.88^{\circ} \mathrm{C}$ (Figure S1), whereas TPA-MC-2 and TPA-MC-3 display the $5 \%$ wt. loss at 
$257.66^{\circ} \mathrm{C}$ (Figure S2) and $185.40^{\circ} \mathrm{C}$ (Figure S3), respectively. These TGA results revealed that all three compounds-TPA-MC-1, TPA-MC-2, and TPA-MC-3—are thermally stable.

\subsection{Theoretical Calculations}

The Gaussian $09 \mathrm{ab}$ initio/DFT quantum chemical calculations were employed to examine the electronic properties of molecular structures [65]. The B3LYP/6-31G(d) level of theory and frequency calculations were carried out to optimize the geometry of TPA-MC-1, TPA-MC-2, and TPA-MC-3 molecules, respectively. The obtained geometries of TPA-MC-1, TPA-MC-2, and TPA-MC-3 via B3LYP/6-31G(d) were further investigated for the better treatment of charge-transfer excitations through time-dependent density functional theory (TD-DFT) and the results are illustrated in Table S1 [66,67]. The effect of dichloromethane was included by means of the polarizable continuum model (PCM). The TD-DFT results show that TPA-MC-1 gives an absorption band at $480 \mathrm{~nm}$ (Figure S5); TPA-MC-2 shows three absorption bands at $677 \mathrm{~nm}, 541 \mathrm{~nm}$, and $468 \mathrm{~nm}$ (Figure S6); and TPA-MC-3 shows absorption bands at $853 \mathrm{~nm}, 542 \mathrm{~nm}$, and $462 \mathrm{~nm}$ (Figure S7). The frontier molecular orbitals (FMO) calculated at B3LYP/6-31G(d) level of theory and generated by using Avogadro as shown in Figure 1 [56,67]. The calculated electronic-density distribution of the highest occupied molecular (HOMO) orbital of TPA-MC-1 is located on the entire molecule. The lowest unoccupied molecular (LUMO) orbital level of TPA-MC-1 is distributed over MC and acetylene bond. The HOMO of TPA-MC-2 distributed over the tetracyanobutadiene (TCBD) and MC subunits, whereas the LUMO is located at TCBD subunit only. The electronic distribution of the HOMO and of TPA-MC-3 is distributed on DCQDCM and MC subunits. The LUMO of TPA-MC-3 is located only on DCQDCM unit. The HOMO and LUMO of TPA-MC-2 and TPA-MC-3 are lower than that of TPA-MC-1 and are attributed to the incorporation of TCBD and DCQDCM subunits, respectively; which, in turn, resulted in a decrease of the energy band gap $\left(E_{g}\right)$ from $2.91301 \mathrm{eV}$ of TPA-MC- 1 to $2.10564 \mathrm{eV}$ of TPA-MC-2 to $1.60603 \mathrm{eV}$ of TPA-MC-3. Thus, the energy levels and band gaps can be tuned by incorporating electron acceptor subunit in the backbone of TPA-MC-1 (D-A- $\pi-\mathrm{D})$.

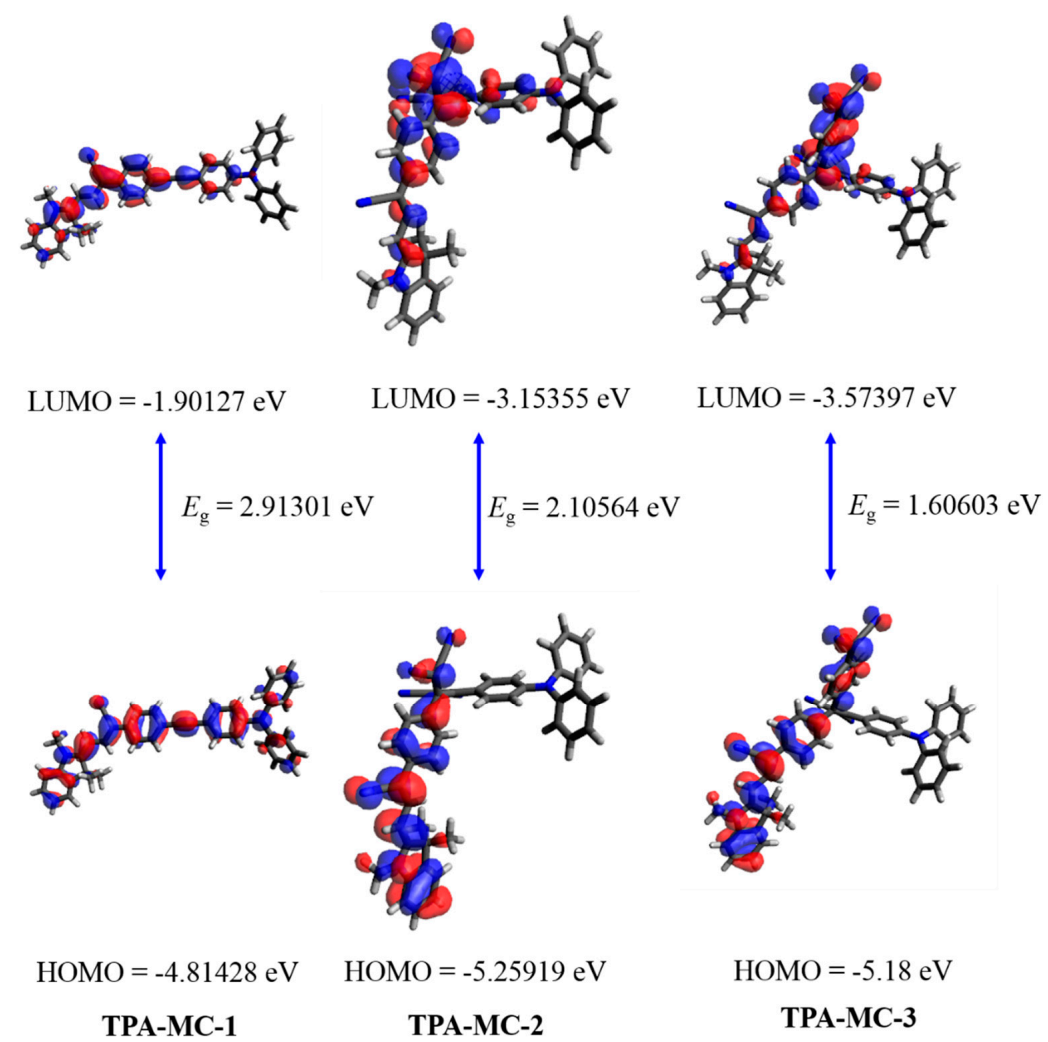

Figure 1. The molecular orbital diagrams of TPA-MC-1, TPA-MC-2, and TPA-MC-3. 


\subsection{Optical and Emission Properties}

The UV-Vis absorption spectra of TPA-MC-1, TPA-MC-2, and TPA-MC-3 molecules in chloroform solution as well as in thin film are depicted (Figure 2). The TPA-MC-1 molecule exhibits strong absorption spectra at $442 \mathrm{~nm}$ along with two more less intense peaks at 364 and $313 \mathrm{~nm}$. The spectrum of TPA-MC-1 in thin film shows an absorption peaks at $445 \mathrm{~nm}$ and $315 \mathrm{~nm}$. The peaks of thin film spectrum broadened with slight red shift. The chloroform solution of TPA-MC-2 displays a strong absorption peak at $595 \mathrm{~nm}$ along with two shoulder peaks at $481 \mathrm{~nm}$ and $282 \mathrm{~nm}$, and its thin film spectrum is broadened and appeared with a bathochromic shift at $631 \mathrm{~nm}$ with shoulder peaks at 498 $\mathrm{nm}$ and $300 \mathrm{~nm}$. The spectra of TPA-MC-3 show strong absorption peaks at $663 \mathrm{~nm}, 483 \mathrm{~nm}$, and a less intense peak at $291 \mathrm{~nm}$. The thin film spectrum of TPA-MC-3 appears at $670 \mathrm{~nm}, 485 \mathrm{~nm}$, and 300 $\mathrm{nm}$, indicating that the molecules pack tightly in solid-state. The absorption peaks of TPA-MC-2 and TPA-MC-3 in solution and thin films are greatly broadened as compare to TPA-MC-1, this is due to the stronger intermolecular interactions and stronger ICT effect in solid-state. The optical band gaps, $E_{\mathrm{g}}$, of TPA-MC-1, TPA-MC-2, and TPA-MC-3 were calculated from their absorption onsets $776 \mathrm{~nm}$, $986 \mathrm{~nm}$, and $1083 \mathrm{~nm}$ of the thin film, and are $1.59 \mathrm{eV}, 1.25 \mathrm{eV}$, and $1.14 \mathrm{eV}$, respectively (Table 1). These results indicate that the incorporation of TCBD and DCQDCM chromophores at the backbone of the TPA-MC-1 displays significant influence on the optical band gaps and light harvesting ability of TPA-MC-2 and TPA-MC-3.

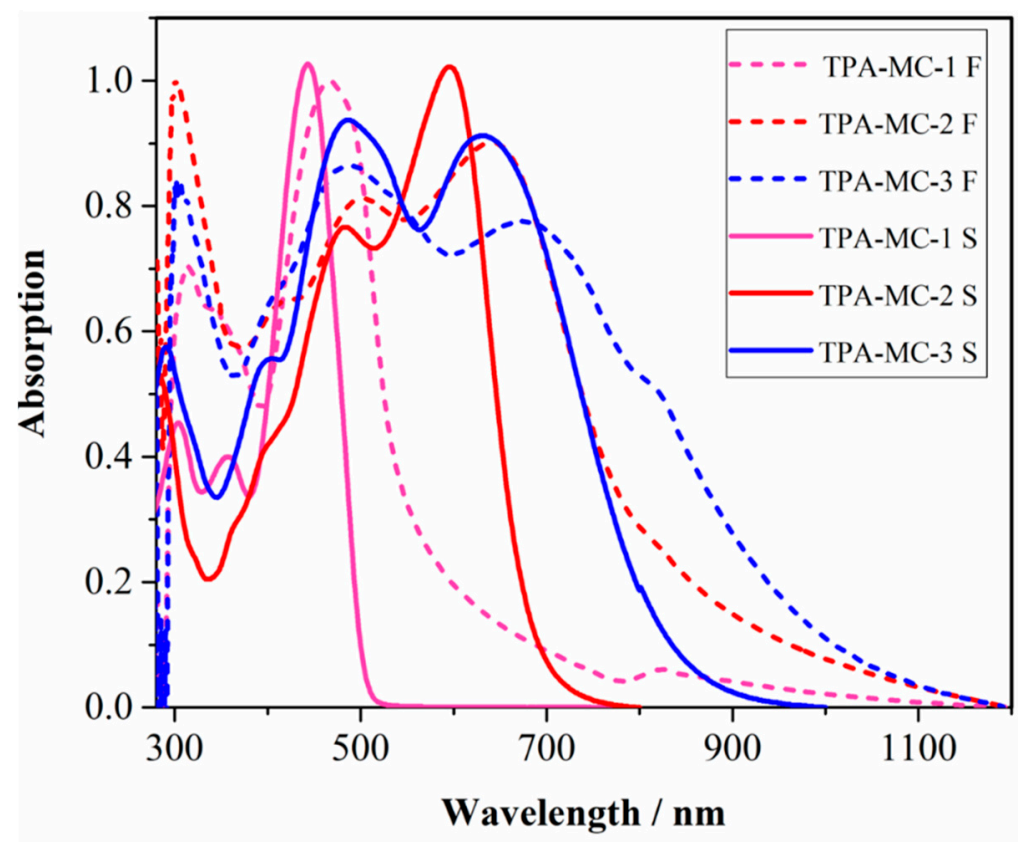

Figure 2. UV-Vis spectra of TPA-MC-1, TPA-MC-2, and TPA-MC-3 in solution (solid lined) and thin film (dashed lines).

Table 1. Optical properties of TPA-MC-1, TPA-MC-2 and TPA-MC-3.

\begin{tabular}{|c|c|c|c|c|}
\hline Acceptor & $\begin{array}{c}\lambda_{\max } \text { Solution } \\
(\mathrm{nm})\end{array}$ & $\begin{array}{c}\lambda_{\max } \text { Film } \\
(\mathrm{nm})\end{array}$ & $\begin{array}{c}\lambda^{\text {onset }} \text { Value Film } \\
\text { (nm) }\end{array}$ & $\begin{array}{c}\text { Optical } \\
\text { Bandgap } E_{g}(\mathrm{eV})^{\text {a }}\end{array}$ \\
\hline TPA-MC-1 & $442,364,313$ & 445,315 & 776 & 1.59 \\
\hline TPA-MC-2 & $\begin{array}{c}595 \\
481,282 \text { (Shoulder) }\end{array}$ & $631,498,300$ & 986 & 1.25 \\
\hline TPA-MC-3 & $663,483,291$ & $670,485,300$ & 1083 & 1.14 \\
\hline
\end{tabular}

a Optical band gap estimated from onset wavelength of film $\left(\lambda_{\text {edge }}\right)$ of the absorption spectra of thin film: $E_{\mathrm{g}}{ }^{\text {opt }}=$ $1240 / \lambda_{\text {edge }}$. 
We also investigated fluorescence spectroscopy of TPA-MC-1, TPA-MC-2, and TPA-MC-3 in chloroform solution upon excitation at $350 \mathrm{~nm}$, as shown in Figure 3. TPA-MC-1 displays the emission main peak at $407 \mathrm{~nm}$ along with three smaller peaks at 434, 469, and $501 \mathrm{~nm}$. The significant strong emission peaks of TPA-MC-2 appeared at $412 \mathrm{~nm}$, along with two additional peaks at $434 \mathrm{~nm}$ and $466 \mathrm{~nm}$. The solution of TPA-MC-3 showed emission peaks at 412, 433, and $468 \mathrm{~nm}$, respectively. This indicates that all three molecules TPA-MC-1, TPA-MC-2, and TPA-MC-3 are light emissive. However, neither of these derivatives produced any emission in the solid thin film; this may be due to overlapping of donor-acceptor system and cause fluorescence.

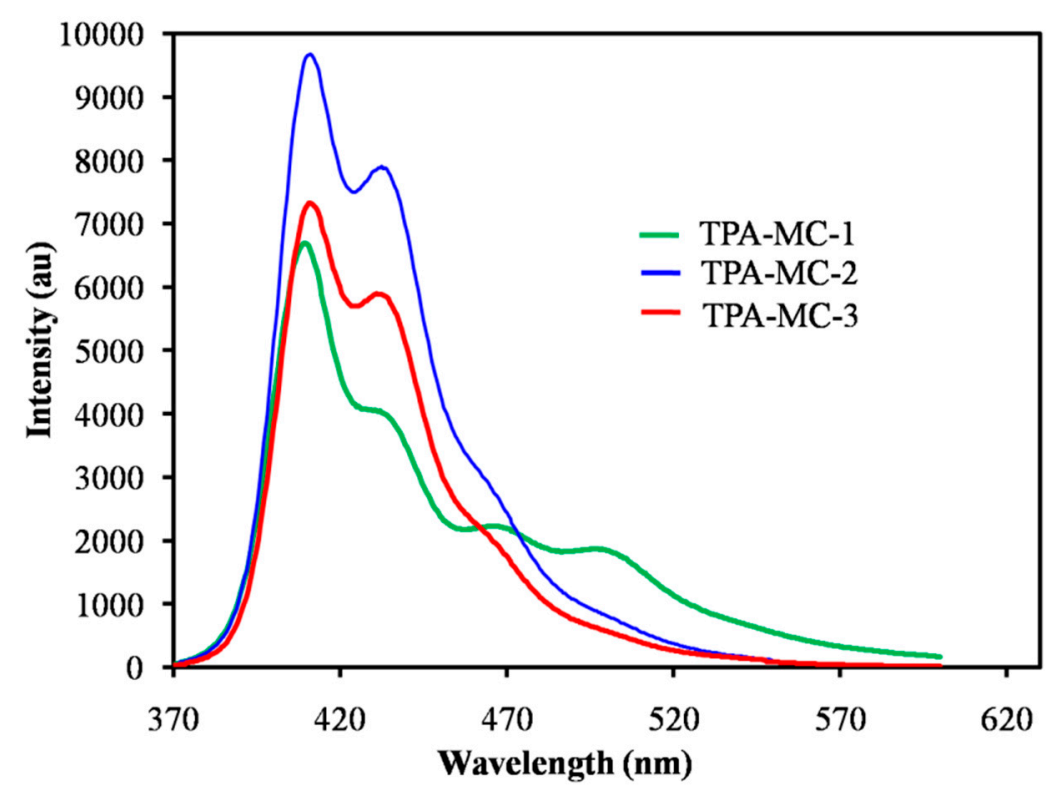

Figure 3. Fluorescence emission spectra of TPA-MC-1, TPA-MC-2, and TPA-MC-3 in chloroform solution $\left(\lambda_{\mathrm{ex}}=350 \mathrm{~nm}\right)$.

\subsection{Electrochemical Properties}

To investigate the electron affinity, semiconductor properties and energy levels of TPA-MC-1, TPA-MC-2, and TPA-MC-3, cyclic voltammetry (CV) measurements [68] in dichlorobenzene were carried out and are depicted in Figure 4; the electrochemical data are summarized in Table 2. The TPA-MC-1 showed the onset oxidation potential at $0.81 \mathrm{~V}$ and the onset reduction potential at $-0.89 \mathrm{~V}$, which corresponds to the subunits present in the molecular backbone. The first onset oxidation and reduction potentials at $0.82 \mathrm{~V}$ and $-0.39 \mathrm{~V}$ are observed for TPA-MC-2-bearing TCBD, and can be ascribed to donor and acceptor subunits, respectively. For TPA-MC-3, the onset oxidation potential and reduction potential are observed at $0.79 \mathrm{~V}$ and $-0.24 \mathrm{~V}$, respectively. Relative to TPA-MC-1, the less-negative onset reduction potentials of TPA-MC-2 and TPA-MC-3 are due to the presence of the electron withdrawing TCBD and DCQDCM subunits in the molecular backbone, respectively. The HOMO and LUMO energy levels of TPA-MC-1, TPA-MC-2, and TPA-MC-3 are calculated from the corresponding onset oxidation and reduction potentials. The estimated HOMO/LUMO energy levels of TPA-MC-1, TPA-MC-2, and TPA-MC-3 are $-5.21 /-3.47 \mathrm{eV},-5.22 /-4.01 \mathrm{eV}$, and $-5.19 /-4.16 \mathrm{eV}$, respectively. As compared to TPA-MC-1 the incorporation of TCBD and DCQDCM subunits in backbone of TPA-MC-1, this resulted in a reduction in energy band gap of TPA-MC-2 and TPA-MC-3. The electrochemical properties of TPA-MC-2 and TPA-MC-3 are matches with energy levels of conventional PC71BM $(-4.20 \mathrm{eV})$ acceptor. Moreover, the energy difference between the conventional donor P3HT and the designed acceptors TPA-MC-1, TPA-MC-2, and TPA-MC-3 (Figure 5) is more than $0.3 \mathrm{eV}$, suggesting the strong electron-withdrawing ability of these new acceptors. 


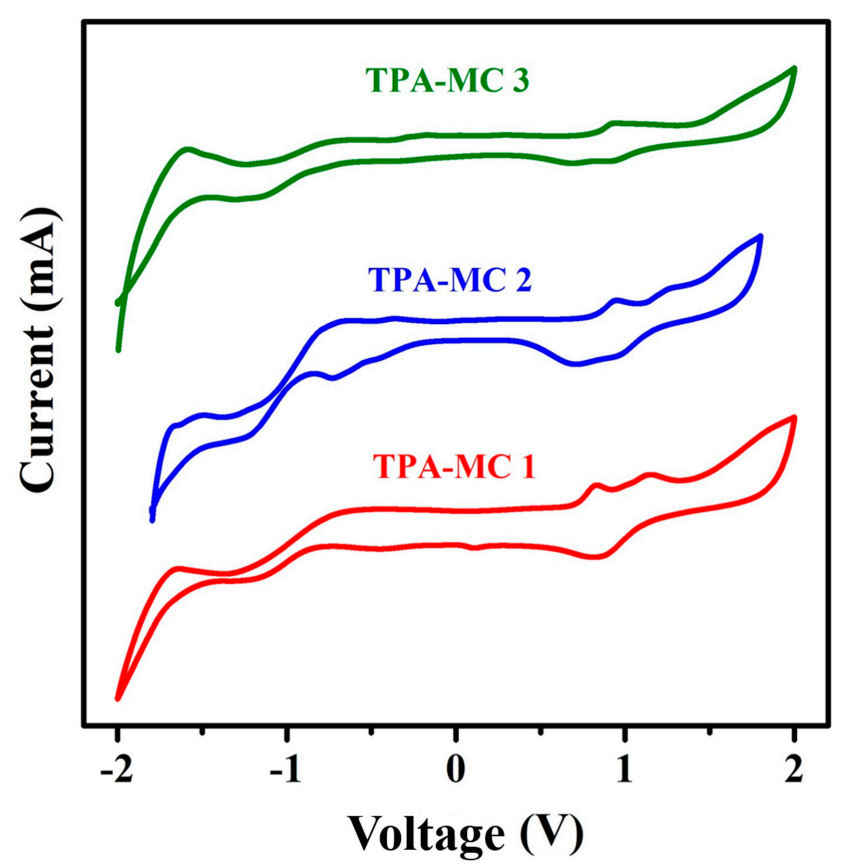

Figure 4. The respective cyclic voltammograms (CV's) of TPA-MC-1, TPA-MC-2, and TPA-MC-3 recorded from dichlorobenzene solution at a scan rate of $50 \mu \mathrm{V} / \mathrm{s}$.

Table 2. Electrochemical properties of TPA-MC-1, TPA-MC-2 and TPA-MC-3.

\begin{tabular}{|c|c|c|c|c|c|}
\hline Acceptor & $\begin{array}{l}\mathrm{E}_{\text {ox }}{ }^{\text {onset }} \\
\text { (V) }\end{array}$ & $\begin{array}{l}\mathrm{E}_{\text {red }}{ }^{\text {onset }} \\
(\mathrm{V})\end{array}$ & 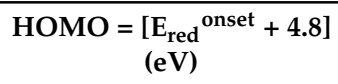 & $\begin{aligned} & \text { LUMO }= {\left[\mathrm{E}_{\text {red }}{ }^{\text {onset }}+4.8\right] } \\
&(\mathrm{eV})\end{aligned}$ & $\begin{array}{c}E_{g}=(\text { HOMO-LUMO }) \\
e V\end{array}$ \\
\hline TPA-MC-1 & 0.81 & -0.89 & -5.21 & -3.47 & 1.74 \\
\hline TPA-MC-2 & 0.82 & -0.39 & -5.22 & -4.01 & 1.21 \\
\hline TPA-MC-3 & 0.79 & -0.24 & -5.19 & -4.16 & 1.03 \\
\hline
\end{tabular}

\subsection{Discussion}

Photophysical properties of TPA-MC-1, TPA-MC-2, and TPA-MC-3 were analyzed using UV-Vis electronic absorption and photoluminescence (PL) spectroscopy. All three compounds displayed strong electronic absorption bands at 300-370 nm, which are attributed to the $\pi-\pi^{*}$ transition of donor and acceptor units. TPA-MC-1, TPA-MC-2, and TPA-MC-3 compounds showed structured PL spectra at 400-500 nm, suggesting that their excited states exhibit some charge-transfer characteristics. The band gap energies calculated from the onset absorption spectra of TPA-MC-1, TPA-MC-2, and TPA-MC-3 are $1.59 \mathrm{eV}, 1.25 \mathrm{eV}$, and $1.14 \mathrm{eV}$, respectively. Whereas the band gap energies calculated from DFT calculations showed the same trend: that the energy gap is higher than that of calculated absorption values. The DFT calculation showed in TPA-MC-3, LUMO is completely localized over acceptor units, indicating separated charge HOMO and LUMO charge distributions. The separated HOMO and LUMO electron distribution resulted from the strong electron-donating ability of triphenylamine and strong electron-withdrawing nature of DCQDCM. Furthermore, the HOMO and LUMO measured by CV are $1.74 \mathrm{eV}, 1.21 \mathrm{eV}$, and $1.03 \mathrm{eV}$ for TPA-MC-1, TPA-MC-2, and TPA-MC-3, respectively. UV-Vis and CV results reveal presence of DCQDCM in backbone of the chromophore is more efficient than TCBD for lowering the LUMO level and energy gap. These measured CV energy gap values are comparable with estimated energy gap values by UV-Vis absorption spectroscopy, which confirm their ability to confine as acceptors.

The UV-Vis, PL, CV, and DFT calculation results suggest that TPA-MC-1, TPA-MC-2, and TPA-MC-3 are potential acceptors in for BHJ applications. 


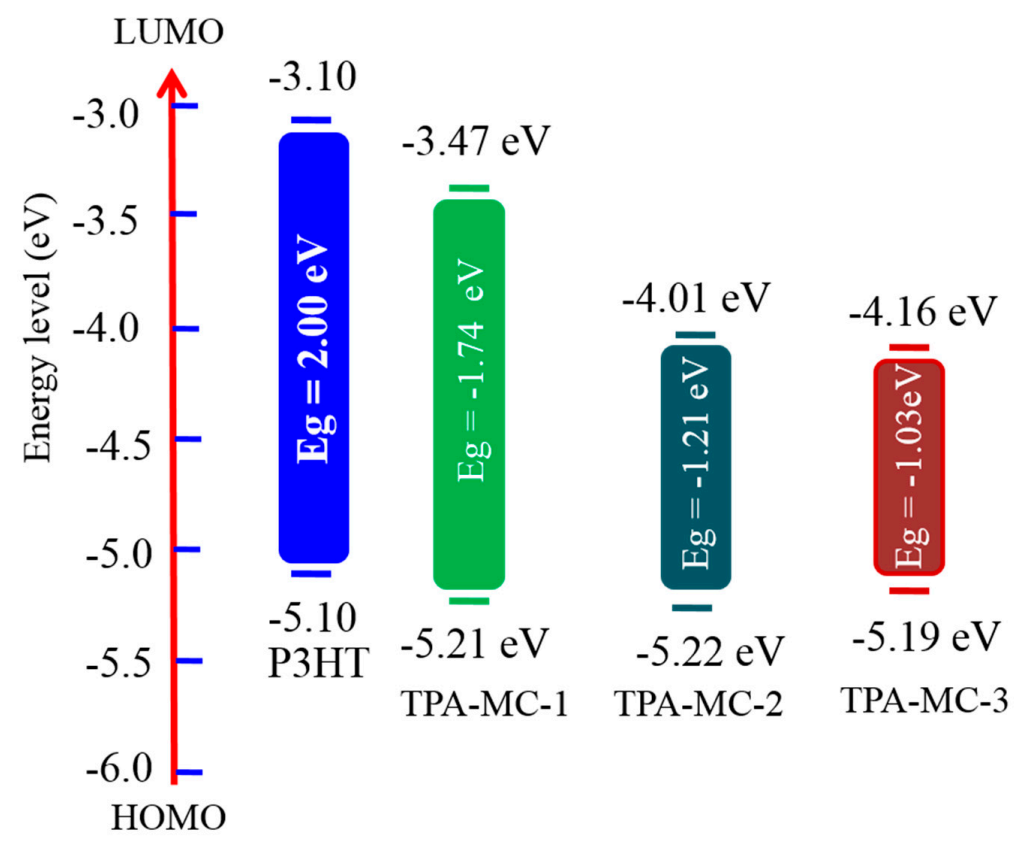

Figure 5. Energy band diagram of P3HT, TPA-MC-1, TPA-MC-2, and TPA-MC-3.

\section{Conclusions}

In summary, we designed and synthesized donor-acceptor chromophores TPA-MC-2 and TPA-MC-3 by [2 + 2] cycloaddition-retroelectrocyclization reaction of TPA-MC-1 and TCBD and a DCQDCM, respectively. The LUMO energy level of the TPA-MC-2 and TPA-MC-3 is lowered by incorporation of TCBD and a DCQDCM as strong electron acceptor subunit. The electrochemical properties of TPA-MC-1, TPA-MC-2, and TPA-MC-3 are matches with energy levels of the conventional PC71BM $(-4.20 \mathrm{eV})$ acceptor. Due to the presence of strong electron acceptors in TPA-MC-2, TPA-MC-3 exhibits strong intramolecular charge-transfer (ICT) interactions, which results in lowering of the LUMO energy level. Thus, we believe these along with similar structures will be good candidates for BHJ devices.

\section{Experimental Section}

\subsection{Materials and Methods}

All the chemicals were purchased from Sigma Aldrich, Bengaluru, Karnataka, India. Triphenylamine, 2-(1,3,3-(Trimethylindoline-2-ylidene)acetaldehyde, 4-iodophenyl acetonitrile, triethylamine, copper iodide, (trimethylsilyl)acetylene, bis(triphenylphosphine) palladium (II) chloride, $\mathrm{K}_{2} \mathrm{CO}_{3}, \mathrm{MgSO}_{4}$, DIPEA, tetrakis (triphenylphosphine) palladium (0), tetracyanoethylene (TCNE), and 7,7,8,8-tetracyanoquinodimethane (TCNQ) were used as-received without further purification unless otherwise mentioned. The moisture sensitized reactions were carried out under nitrogen atmosphere using freeze-thaw-pump cycle method. Solvents were purchased from SD Fine, India and are AR grade. The solvents were distilled before use. The structure of prepared compounds was confirmed by using modern spectroscopic techniques. The progress of reactions was monitored by TLC. The TLC results were visualized by a UV light ( 254 or $356 \mathrm{~nm}$ ). IR spectra were recorded on Thermo Nicolet Nexus 670. ${ }^{1} \mathrm{H}$ NMR (300 MHz and $\left.400 \mathrm{MHz}\right)$ spectra and ${ }^{13} \mathrm{C}$ NMR $(75 \mathrm{MHz}$ and $100 \mathrm{MHz}$ ) were measured at $298 \mathrm{~K}$ using $\mathrm{CDCl}_{3}$ as a solvent. Tetramethylsilane $(\delta=0 \mathrm{ppm})$ was used as an internal standard. ESI-MS data were taken on Shimadzu lab solution mass spectrometer. High-resolution mass spectra (HRMS) spectrometry (Thermofisher Exactive Orbitrap) and atmospheric-pressure chemical ionization (APCI) experiments were carried out on Fourier-transform mass spectroscopy (FTMS). UV-Vis absorption was recorded on a UV-Vis-1800 spectrometer (Shimadzu, Japan) in $\mathrm{CHCl}_{3}$ solvent 
and thin film on quartz surface at room temperature. Florescence spectra were recorded on R-6000 spectrofluorophotometer (Shimadzu, Japan) in $\mathrm{CHCl}_{3}$ solvent. Thermal stability was analyzed by thermogravimetric analysis (TGA) at the heating rate $10{ }^{\circ} \mathrm{C}$ per min under nitrogen atmosphere. The cyclic voltammograms were measured on Power Lab ML160 potentiostat interfaced via a Power Lab $4 / 20$ controller to a PC running E-Chem for Windows version 1.5.2 electrochemical analyzer. The cyclic voltammetry experiments were performed using tetra butyl ammonium hexaflurophospate $\left(\mathrm{TBAPF}_{6}\right.$, $1.0 \mathrm{M}$ ) as supporting electrolyte, $\mathrm{Pt}$ as a working electrode, $\mathrm{Pt}$ wire used as a counter electrode and saturated calomel electrode $(\mathrm{SCE})(\mathrm{Ag} / \mathrm{AgCl}$ in saturated $\mathrm{KCl})$ used as a reference electrode.

\subsection{Synthetic Procedure of Compound 1}

In a $250-\mathrm{mL}$ round bottom flask, triphenylamine $(3.00 \mathrm{~g}, 12.2 \mathrm{mmoL})$ was dissolved in the mixture of chloroform $(60 \mathrm{~mL})$ and acetic acid $(60 \mathrm{~mL})$ in the same equimolar ratio $(1: 1, v / v)$. The $\mathrm{N}$-iodosuccinamide $(2.75 \mathrm{~g}, 12.2 \mathrm{mmoL})$ was added and then reaction mixture was stirred at room temperature about $12 \mathrm{~h}$ under dark condition. The completion of reaction was confirmed by TLC. The reaction mixture was poured into water and extracted with $\mathrm{CHCl}_{3}$. The organic layer was washed with water. The excess iodine was quenched with saturated $\mathrm{Na}_{2} \mathrm{~S}_{2} \mathrm{O}_{3}$. The obtained colorless organic layer was dried over sodium sulfate. The combined organic layer was concentrated under reduced pressure. The residue, colorless oily liquid, was dried under vacuum. The crude product was washed with hexane (2-3 times) to yield white powder as $1(4.17 \mathrm{~g}, 92 \%) .{ }^{1} \mathrm{H} \mathrm{NMR}\left(400 \mathrm{MHz}, \mathrm{CDCl}_{3}\right) \delta 7.51$ (d, $J=8.8 \mathrm{~Hz}, 2 \mathrm{H}), 7.24(\mathrm{t}, J=8.4 \mathrm{~Hz}, 4 \mathrm{H}), 7.106 .99(\mathrm{~m}, 4 \mathrm{H}), 6.82(\mathrm{~d}, J=8.9 \mathrm{~Hz}, 2 \mathrm{H})$.

\subsection{Synthetic Procedure of Compound 2}

(a) A mixture of compound 1 ( $3 \mathrm{~g}, 8.08 \mathrm{mmoL})$, ethynyltrimethylsilane ( $3.36 \mathrm{~mL}, 24.2 \mathrm{mmoL})$, and $\mathrm{CuI}(76 \mathrm{mg}, 0.40 \mathrm{mmol})$ were dissolved in mixture of triethylamine $(30 \mathrm{~mL})$ and dry THF $(30 \mathrm{~mL})$. $\mathrm{The} \mathrm{Pd}\left(\mathrm{PPh}_{3}\right)_{2} \mathrm{Cl}_{2}$ (ca. $5 \mathrm{~mol} \%$ ) was added to the reaction mixture under nitrogen atmosphere. The resulting mixture was refluxed for $12 \mathrm{~h}$ under nitrogen atmosphere. The progress of reaction was monitored by TLC. After completion of reaction, the reaction mixture was poured into $200 \mathrm{~mL}$ of water and extracted with DCM (2-3 times). The combined organic layer was dried over anhydrous $\mathrm{Na}_{2} \mathrm{SO}_{4}$. The solvent was concentrated under reduced pressure to yield 2 as yellow oil. The obtained crude product was used in next step without purification.

(b) Compound 2 was dissolved in the mixture of $30 \mathrm{~mL}$ of THF and $30 \mathrm{~mL}$ of methanol. The dry fine powder of $\mathrm{K}_{2} \mathrm{CO}_{3}(2.6 \mathrm{~g})$ was added to the reaction mixture. The resulting mixture was stirred for $4 \mathrm{~h}$ at room temperature. The completion of reaction was monitored by TLC. The solvent was evaporated under reduced pressure. The obtained crude product was diluted with DCM and filtered off. The organic solvent was concentrated under reduced pressure. The obtained crude product was purified by column chromatography on silica gel to afford light yellow solid 3 (yield, $70 \%$ ). ${ }^{1} \mathrm{H}$ NMR $\left(400 \mathrm{MHz}, \mathrm{CDCl}_{3}\right)$ \& 7.34-7.30 (m, 2H), 7.297.24 (m, 4H), 7.107.03 (m, 6H), 7.986.94 (m, 2H), 3.01 (s, 1H); ${ }^{13} \mathrm{C}$ NMR $\left(125 \mathrm{MHz}, \mathrm{CDCl}_{3}\right) \delta 148.33,147.09,133.03,129.38,125.02,123.60,122.02,114.72,76.14$.

\subsection{Synthetic Procedure of Compound 6}

4-Iodo phenyl acetonitrile 4 ( $1 \mathrm{~g}, 4.1 \mathrm{mmoL})$ was dissolved in freshly prepared dry THF $(20 \mathrm{~mL})$. Piperidine $(1 \mathrm{~mL})$ was added to this reaction mixture under nitrogen atmosphere. The resulting reaction mixture was refluxed for $1 \mathrm{~h}$. The 2-(1, 3, 3-trimethylindolin-2-ylidene) acetaldehyde 5 ( $1 \mathrm{~g}$, $4.9 \mathrm{mmoL}$ ) was added to the reaction mixture at refluxed temperature and continued the reaction for $12 \mathrm{~h}$. The progress of reaction was monitored with TLC. After completion of reaction, the excess aldehyde was washed with chilled methanol. This process was performed till the complete removal of aldehyde. The obtained product was dried over vacuum to yield shiny dark yellow compound $\mathbf{6}$ (1.50 g, yield: 86\%). FT-IR (in KBr, $\mathrm{cm}^{-1}$ ): 3050.13, 2966.11, 2192.35, 1589.82, 1564.09, 14484.37, 1334.73, 1203.73, 1120.90, 981.30, 746.59, $706.20 \mathrm{~cm}^{-1} ;{ }^{1} \mathrm{H}$ NMR $\left(400 \mathrm{MHz}, \mathrm{CDCl}_{3}\right) \delta 7.82(\mathrm{~d}, J=12.7 \mathrm{~Hz}, 1 \mathrm{H})$, $7.68(\mathrm{~d}, J=8.6 \mathrm{~Hz}, 2 \mathrm{H}), 7.27-7.20(\mathrm{~m}, 4 \mathrm{H}), 6.98(\mathrm{t}, J=7.4,6.7 \mathrm{~Hz}, 1 \mathrm{H}), 6.79(\mathrm{~d}, J=7.9 \mathrm{~Hz}, 1 \mathrm{H}), 5.87(\mathrm{~d}$, 
$J=12.7 \mathrm{~Hz}, 1 \mathrm{H}), 3.29(\mathrm{~s}, 3 \mathrm{H}), 1.63(\mathrm{~s}, 6 \mathrm{H}) ;{ }^{13} \mathrm{C} \mathrm{NMR}\left(100 \mathrm{MHz}, \mathrm{CDCl}_{3}\right) \delta 164.86,144.05,138.90,137.89$, 135.06, 128.15, 125.98, 121.62, 121.40, 118.49, 107.32, 99.40, 94.40, 91.25, 46.65, 29.57, 28.83. ESI-Mass m/z $427[\mathrm{M}+\mathrm{H}]^{+}$; HRMS: Chemical Formula: $\mathrm{C}_{21} \mathrm{H}_{19} \mathrm{IN}_{2} \mathrm{~m} / \mathrm{z}$ calculated $427.0646[\mathrm{M}+\mathrm{H}]^{+}$, found: $427.0665[\mathrm{M}+\mathrm{H}]^{+}$.

\subsection{Synthetic Procedure of TPA-MC-1}

The mixture of dry THF $(10 \mathrm{~mL})$ and dry DIPEA $(10 \mathrm{~mL})$ was deoxygenated under nitrogen atmosphere for $30 \mathrm{~min}$. Compound 6 ( $500 \mathrm{mg}, 1.17 \mathrm{mmoL}$ ) and compound 3 ( $347 \mathrm{mg}, 1.29 \mathrm{mmoL}$ ) were added to the reaction mixture. The resulting reaction mixture was carefully degassed and recharged with $\mathrm{N}_{2}$ gas. A catalytic amount of tetrakis (triphenylphosphine)palladium (0) (ca. $5 \mathrm{moL} \%$ ) and copper iodide $(12 \mathrm{mg}, 0.05 \mathrm{mmoL}$ ) were added simultaneously. The resulting reaction mixture was stirred under reflux for $12 \mathrm{~h}$. The completion of reaction was monitored with TLC. The reaction mixture was cooled to room temperature. The solvent was removed under reduced pressure. The obtained residue was dissolved in excess DCM and passed through celite. The obtained filtrate was concentrated under reduced pressure. The crude product was purified by column chromatography on silica gel (60/120 mesh) with dichloromethane/hexane (3: 6) as an eluent to afford TPA-MC-1 as a dark orange solid (546 mg, yield: 82\%). FT-IR (in $\mathrm{KBr}, \mathrm{cm}^{-1}$ ): 3447.42, 3031.13, 2923.17, 2195.35, 1572.15, 1510.82, 1487.41, 1386.64, 1332.91, 1273.40, 1199.75, 1120.04, 1075.10, 924.71, 814.64, 746.63, 694.14, $514.69 \mathrm{~cm}^{-1} ;{ }^{1} \mathrm{H}$ NMR $\left(400 \mathrm{MHz}, \mathrm{CDCl}_{3}\right) \delta 7.86(\mathrm{~d}, J=12.7 \mathrm{~Hz}, 1 \mathrm{H}), 7.507 .45(\mathrm{~m}, 4 \mathrm{H}), 7.397 .36$ $(\mathrm{m}, 2 \mathrm{H}), 7.297 .20(\mathrm{~m}, 7 \mathrm{H}), 7.136 .96(\mathrm{~m}, 9 \mathrm{H}), 6.79(\mathrm{~d}, J=7.9 \mathrm{~Hz}, 1 \mathrm{H}), 5.91(\mathrm{~d}, J=12.7 \mathrm{~Hz}, 1 \mathrm{H}), 3.30(\mathrm{~s}, 3 \mathrm{H})$, 1.65(s, 6H); ${ }^{13} \mathrm{C}$ NMR $\left(100 \mathrm{MHz}, \mathrm{CDCl}_{3}\right) \delta 164.64,147.88,147.15,144.13,139.02,138.64,134.57,132.47$, 131.91, 131.63, 129.36, 128.54, 128.08, 124.95, 124.00, 123.52, 122.28, 121.67, 121.37, 118.63, 116.04, 107.34, 100.11, 94.61, 90.66, 88.70, 46.65, 29.59, 28.87, 28.36; ESI-Mass m/z 568 [M+H] ${ }^{+}$; HRMS: Chemical Formula: $\mathrm{C}_{41} \mathrm{H}_{33} \mathrm{~N}_{3}$ calculated $\mathrm{m} / \mathrm{z} 567.2666[\mathrm{M}]^{+}$, found: $567.2669[\mathrm{M}]^{+}$.

\subsection{Synthetic Procedure of TPA-MC-2}

The compound TPA-MC-1 (100 mg, $0.17 \mathrm{mmoL})$ was dissolved in dry dichloromethane $(5 \mathrm{~mL})$. To this reaction mixture, tetracyanoethylene $(33 \mathrm{mg}, 0.26 \mathrm{mmoL})$ was added. After addition of TCNE, immediate color change of reaction mixture was observed. The progress of reaction was monitored by TLC. After $2 \mathrm{~h}$, the starting material was completely consumed. The solvent was concentrated under reduced pressure and the residue was purified by column chromatography on silica gel with DCM/hexane (8:2) as eluent to get dark purple color solid TPA-MC-2 (116 mg, 95\%). FT-IR (in KBr, $\left.\mathrm{cm}^{-1}\right): 2923.82,22,2218.20,2197.17,1587.61,1562.93,1485.71,1426.26,1338.47,1288.33,1256.41,1203.32$, 1175.43, 1118.93, 1049.24, 930.55, 816.00, 749.34, 698.03, 522.2 $\mathrm{cm}^{-1} ;{ }^{1} \mathrm{H}$ NMR $\left(400 \mathrm{MHz}, \mathrm{CDCl}_{3}\right) \delta 8.05$ $(\mathrm{d}, J=12.9 \mathrm{~Hz}, 1 \mathrm{H}), 7.79(\mathrm{~d}, J=8.9 \mathrm{~Hz}, 2 \mathrm{H}), 7.68(\mathrm{~d}, J=9.2 \mathrm{~Hz}, 2 \mathrm{H}), 7.62(\mathrm{~d}, 8.9 \mathrm{~Hz}, 2 \mathrm{H}), 7.427 .38(\mathrm{~m}$, $4 \mathrm{H}), 7.327 .27(\mathrm{~m}, 4 \mathrm{H}), 7.247 .21(\mathrm{~m}, 5 \mathrm{H}), 7.097 .05(\mathrm{~m}, 1 \mathrm{H}), 6.94(\mathrm{~d}, J=9.2 \mathrm{~Hz}, 2 \mathrm{H}), 6.89(\mathrm{~d}, J=7.9 \mathrm{~Hz}, 1 \mathrm{H})$, 3.38 (s, 3H), $1.66(\mathrm{~s}, 6 \mathrm{H}) .{ }^{13} \mathrm{C} \mathrm{NMR}\left(100 \mathrm{MHz}, \mathrm{CDCl}_{3}\right) \delta 167.89,166.44,164.20,153.73,144.48,143.50$, 141.64, 139.36, 131.85, 130.46, 130.06, 128.33, 126.92, 126.68, 124.51, 122.68, 121.86, 121.54, 118.04, 117.81, 113.58, 112.76, 112.95, 108.26, 97.40, 95.49, 83.11, 47.43, 29.95, 29.67, 28.88; ESI-Mass m/z 696 [M] ${ }^{+}$; HRMS: Chemical Formula: $\mathrm{C}_{47} \mathrm{H}_{33} \mathrm{~N}_{7}$ calculated $\mathrm{m} / \mathrm{z} 696.2906[\mathrm{M}+\mathrm{H}]^{+}$, found: $696.2870[\mathrm{M}+\mathrm{H}]^{+}$.

\subsection{Synthetic Procedure of TPA-MC-3}

To a solution of TPA-MC-1 (100 mg, $0.17 \mathrm{mmoL})$ in dry THF $(5 \mathrm{~mL})$, TCNQ $(53 \mathrm{mg}, 0.26 \mathrm{mmol})$ was added. The resulting reaction mixture was refluxed for $24 \mathrm{~h}$. The progress of reaction was monitored by TLC. After completion of reaction, the solvent was evaporated under reduced pressure. The obtained crude product was purified by column chromatography on silica to yield black solid TPA-MC-3 (121 $\mathrm{mg}, 89 \%$ ). FT-IR (in KBr, cm ${ }^{-1}$ ): 2923.08, 2205.44, 1556.92, 1488.49, 1413.25, 1386.02, 1317.82, 1178.999, 1119.71, 1019.22, 923.54, 835.07, 809.83, 748.78, 697.30, 522.86 $\mathrm{cm}^{-1} ;{ }^{1} \mathrm{H}$ NMR $\left(400 \mathrm{MHz}, \mathrm{CDCl}_{3}\right) \delta$ 8.02-7.96 (m, $1 \mathrm{H}), 7.71-7.70(\mathrm{~m}, 2 \mathrm{H}), 7.62-7.53(\mathrm{~m}, 4 \mathrm{H}), 7.39-7.35(\mathrm{~m}, 5 \mathrm{H}), 7.31-7.17(\mathrm{~m}, 11 \mathrm{H})$, 7.08-7.03(m, 1H), 6.89-6.84 (m, $2 \mathrm{H}), 5.98(\mathrm{~d}, J=12.9 \mathrm{~Hz}, 1 \mathrm{H}), 3.37-3.36(\mathrm{~m}, 3 \mathrm{H}), 1.66-1.65(\mathrm{~m}, 6 \mathrm{H}) ;{ }^{13} \mathrm{C}$ 
NMR $\left(100 \mathrm{MHz}, \mathrm{CDCl}_{3}\right) \delta 170.08,167.56,166.71,154.02,151.54,151.01,145.32,144.69,143.54,141.72$, 141.27, 140.43, 139.26, 135.23, 134.24, 133.33, 132.69, 132.12, 131.08, 130.67, 129.87, 128.33, 126.86, 126.55, $125.83,125.53,124.43,122.58,121.82,119.28,117.91,114.08,113.52,112.78,108.19,97.79,95.33,84.00$, 74.21, 47.34, 29.92, 28.89, 14.10; ESI-Mass m/z $772[\mathrm{M}+\mathrm{H}]^{+}$; HRMS: Chemical Formula: $\mathrm{C}_{47} \mathrm{H}_{33} \mathrm{~N}_{7}$ calculated $\mathrm{m} / \mathrm{z} 772.3212[\mathrm{M}+\mathrm{H}]^{+}$, found: $772.3183[\mathrm{M}+\mathrm{H}]^{+}$.

Supplementary Materials: Supplementary materials can be found at http:/ /www.mdpi.com/1422-0067/20/7/ 1621/s1.

Author Contributions: Conceptualization: S.V.B. (Sidhanath V. Bhosale); methodology: P.S.R.; computational study: A.L.P.; validation of UV-vis, emission and CV: S.V.B. (Sheshanath V. Bhosale) (GU); manuscript writing: S.V.B. (Sheshanath V. Bhosale). (IICT) and S.V.B. (Sidhanath V. Bhosale) (GU).

Funding: This research received no external funding.

Acknowledgments: S.V.B. (Sidhanath V. Bhosale) (IICT) is grateful for financial support from The Director, CSIR-IICT, Hyderabad, India and IICT/Pubs./2019/073. S.V.B. (Sheshanath V. Bhosale) (GU) acknowledges financial support from the University Grant Commission under faculty recharge programme. P.S.R. would like to thank CSIR for SRF. ALP acknowledges use of Gaussian 09 procured under the DST-FIST Scheme (Sanction No. FS/FST/PSI-018/2009).

Supporting Information: TGA, Molecular orbital diagrams, calculated TA-DFT, computed absorption spectras, ${ }^{1} \mathrm{H}$ NMR, ${ }^{13} \mathrm{C}$ NMR, FT-IR, mass and HRMS are given in SI.

Conflicts of Interest: The authors declare no conflict of interest.

\section{Abbreviations}

$\begin{array}{ll}\text { CV } & \text { Cyclic Voltammetry } \\ \text { DCQDCM } & \text { Dicyanoquinodicyanomethane } \\ \text { HOMO } & \text { Highest occupied molecular orbital } \\ \text { ICT } & \text { Intramolecular charge-transfer } \\ \text { LUMO } & \text { Lowest unoccupied molecular orbital } \\ \text { MC } & \text { Merocyanine } \\ \text { TCBD } & \text { 1,1,4,4-tetracyanobutadiene } \\ \text { TCNE } & \text { Tetracyanoethene } \\ \text { TCNQ } & \text { 7.7.8,8-tetracyanoquinodimethane } \\ \text { TPA } & \text { Triphenylamine } \\ \text { UV-Vis } & \text { Ultraviolet Visible }\end{array}$

\section{References}

1. Yu, G.; Gao, J.; Hummelen, J.C.; Wudl, F.; Heeger, A.J. Polymer photovoltaic cells: Enhanced efficiencies via a network of internal donor-acceptor heterojunctions. Science 1995, 270, 1789-1791. [CrossRef]

2. Halls, J.J.M.; Walsh, C.A.; Greenham, N.C.; Marseglia, E.A.; Friend, R.H.; Moratti, S.C.; Holmes, A.B. Efficient photodiodes from interpenetrating polymer networks. Nature 1995, 376, 498-500. [CrossRef]

3. Dempsey, J.L.; Esswein, A.J.; Manke, D.R.; Risenthal, J.; Soper, J.D.; Nocera, D.G. Molecular chemistry of consequence to renewable energy. Inorg. Chem. 2005, 44, 6879-6892. [CrossRef] [PubMed]

4. Sen, R.; Singh, S.P.; Johari, P. Strategical designing of donor-acceptor-donor based organic molecules for tuning their linear optical properties. J. Phys. Chem. A 2018, 122, 492-504. [CrossRef] [PubMed]

5. Hashemi, D.; Ma, X.; Ansari, R.; Kim, J.; Kieffer, J. Design principles for the energy level tuning in donor/acceptor conjugated polymers. Phys. Chem. Chem. Phys. 2019, 21, 789-799. [CrossRef]

6. Cnops, K.; Zango, G.; Genoe, J.; Heremans, P.; Martinez-Diaz, M.V.; Torres, T.; Cheyns, D. Energy level tuning of non-fullerene acceptors in organic solar cells. J. Am. Chem. Soc. 2015, 137, 8991-8997. [CrossRef] [PubMed]

7. Panneerselvam, M.; Kathiravan, A.; Solomon, R.V.; Jaccob, M. The role of $\pi$-linkers in tuning optoelectronic properties of triphenylamine derivatives for solar cell applications-A DFT/TDDFT study. Phys. Chem. Chem. Phys. 2017, 19, 6153-6163. [CrossRef] 
8. Tarsang, R.; Promarak, V.; Sudyoadsuk, T.; Namuangruk, S.; Jungsuttiwong, S. Tuning the electron donating ability in the triphenylamine-based D- $\pi$-A architecture for highly efficient dye-sensitized solar cells. J. Photochem. Photobiol. A Chem. 2014, 273, 8-16. [CrossRef]

9. Liu, Y.; Kong, M.; Zhang, Q.; Zhang, Z.; Zhou, H.; Zhnag, S.; Li, S.; Wu, J.; Tian, Y. A series of triphenylamine-based two-photon absorbing materials with AIE property for biological imaging. J. Mater. Chem. B 2014, 2, 5430-5440. [CrossRef]

10. Rao, P.S.; Gupta, A.; Zhang, F.; Bilic, A.; Xiang, W.; Evans, R.A.; Bhosale, S.V. Donor-acceptor-acceptor sketched non-fullerene acceptors carrying terminal chromen-2-one functionality for solution-processable organic photovoltaic devices. Dyes Pigm. 2017, 146, 502-511.

11. Michinobu, T.; Diederich, F. The [2+2] cycloaddition-retrocyclization (CA-RE) click reaction: Facile access to molecular and polymeric push-pull chromophores. Angew. Chem. Int. Ed. 2018, 57, 2-28. [CrossRef] [PubMed]

12. Kivala, M.; Diederich, F. Acetylene-derived strong organic acceptors for planar and non-planar push-pull chromophores. Acc. Chem. Res. 2009, 42, 235-248. [CrossRef]

13. Zucchero, A.J.; McGrier, P.L.; Bunz, U.H.F. Cross-conjugated cruciform fluorophores. Acc. Chem. Res. 2010, 43, 397-408. [CrossRef] [PubMed]

14. Gholami, M.; Tykwinski, R.R. Oligomeric and polymeric systems with a cross-conjugated $\pi$-framework. Chem. Rev. 2006, 106, 4997-5027. [CrossRef] [PubMed]

15. Lew, W.C.W.; Hartley, C.S. A push-pull macrocycle with both linearly conjugated and cross-conjugated bridges. Org. Lett. 2013, 15, 3762-3765.

16. Shoji, T.; Kamata, N.; Maruyama, A.; Ito, S.; Okujima, T. Synthesis, properties, and redox behavior of ferrocenyl-1,1,4,4-tetracyano-1,3-butadienes connected by arylamine and azobenzene spacers. Bull. Chem. Soc. Jpn. 2015, 88, 1338-1346. [CrossRef]

17. Štefko, M.; Tzirakis, M.D.; Breiten, B.; Ebert, M.-O.; Dumele, O.; Schweiser, W.B.; Gisselbrecht, J.-P.; Boudon, C.; Beels, M.T.; Biaggio, I.; et al. Donor-acceptopr (D-A)-substituted polyyne chromophores: Modulation of their optoelectronic properties by varying the length of the acetylene spacers. Chem. Eur. J. 2013, 19, 12693-12704. [CrossRef] [PubMed]

18. Mi, Y.; Liang, P.; Yang, Z.; Wang, D.; Cao, H.; He, W.; Yang, H.; Yu, L. Application of near-IR absorption porphyrin dyes derived from clock chemistry as third-order nonlinear optical materials. ChemistryOpen 2015, 5, 71-77. [CrossRef]

19. Fujita, H.; Michinobu, T.; Fukuta, S.; Koganezawa, T.; Higashihara, T. Sequentially different AB diblock and ABA triblock copolymers as P3HT:PCBM interfacial compatibilizers for bulk-heterojunction photovoltaics. ACS Appl. Mater. Interfaces 2016, 8, 5484-5492. [CrossRef] [PubMed]

20. Rout, Y.; Gautam, P.; Misra, R. Unsymmetrical and symmetrical push-pull phenothiazines. J. Org. Chem. 2017, 82, 6840-6845. [CrossRef]

21. Rijkers, D.T.S.; Diederich, F. A convenient synthesis of new chromophoric tetracyanobutadiene-scaffolded peptides via a dipolar [2+2] cycloaddition-cycloreversion reactions. Tet. Lett. 2011, 52, 4021-4025. [CrossRef]

22. Patil, Y.; Misra, R. Diketopyrrolopyrrole-based and tetracyano-bridged small molecules for bulk heterojunction organic solar cells. Chem. Asian J. 2018, 13, 220-229. [CrossRef] [PubMed]

23. Leliège, A.; Blanchard, P.; Rousseau, T.; Roncali, J. Triphenylamine/tetracyanobutadiene-based D-A-D $\pi$-conjugated systems as molecular donors for organic solar cells. Org. Lett. 2011, 13, 3098-3101. [CrossRef]

24. Michinobu, T.; Satoh, N.; Cai, J.; Li, Y.; Han, L. Novel design of organic donor-acceptor dyes without carboxylic acid anchoring groups for dye-sensitized solar cells. J. Mater. Chem. C 2014, 2, 3367-3372. [CrossRef]

25. Zhang, H.; Wan, X.; Xue, X.; Li, Y.; Yu, A.; Chen, Y. Selective tuning of the HOMO-LUMO gap of carbazole-based donor-acceptor-donor compounds toward different emission colors. Eur. J. Org. Chem. 2010, 2010, 1681-1687. [CrossRef]

26. Gregory, P. High Technology Application of Organic Colorants; Plenum: New York, NY, USA, 1991.

27. Blanchard-Desce, M. Molecular engineering of NLO-phores for new NLO microscopies Nouvelles techniques d'imagerie multiphonique: Versune nouvelle génération de marqueurs moléculaires. C. R. Phys. 2002, 3, 439-448. [CrossRef]

28. Verbiest, T.; Houbrechts, S.; Kauranen, M.; Clays, K.; Persoons, A. Second-order nonlinear optical materials: Recent advances in chromophore design. J. Mater. Chem. 1997, 7, 2175-2189. [CrossRef] 
29. Marder, S.R.; Perry, J.W. Molecular materials for second-order nonlinear optical applications. Adv. Mater. 1993, 5, 804-815. [CrossRef]

30. Chen, R.; Yang, X.; Tian, H.; Wang, X.; Hagfeldt, A.; Sun, L. Effect of tetrahydroquinoline dyes structure on the performance of organic dye-sensitized solar cells. Chem. Mater. 2007, 19, 4007-4015. [CrossRef]

31. Hagberg, D.P.; Edvinsson, T.; Mariando, T.; Boschloo, G.; Hagfeldt, A.; Sun, L. A novel organic chromophore for dye-sensitized nanostructured solar cells. Chem. Commun. 2006, 2245-2247. [CrossRef]

32. Horiuchi, T.; Miura, H.; Uchida, S. Highly-efficient metal-free organic dyes for dye-sensitized solar cells. Chem. Commun. 2003, 3036-3037. [CrossRef]

33. Li, S.; Jiang, K.; Shao, K.; Yang, L. Novel organic dyes for efficient dye-sensitized solar cells. Chem. Commun. 2006, 2792-2794. [CrossRef]

34. Ito, S.; Zakeeruddin, S.M.; Humphry-Baker, R.; Liska, P.; Charvet, R.; Comte, P.; Nazeeruddin, M.K.; Péchy, P.; Takata, M.; Miura, H.; et al. High-efficiency organic-dye-sensitized solar cells controlled by nanocrystalline- $\mathrm{TiO}_{2}$ electrode thickness. Adv. Mater. 2006, 18, 1202-1205. [CrossRef]

35. Sayama, K.; Hara, K.; Mori, N.; Satsuki, M.; Suga, S.; Tsukagoshi, S.; Abe, Y.; Sugihara, H.; Arakawa, H. Photosensitization of a porous $\mathrm{TiO}_{2}$ electrode with merocyanine dyes containing a carboxyl group and a long alkyl chain. Chem. Commun. 2000, 1173-1174. [CrossRef]

36. Würthner, F.; Thalacker, C.; Matschiner, R.; Lukaszuk, K.; Wortmann, R. Optimization of neutrocyanine chromophores based on five-membered heterocycles for photorefractive applications. Chem. Commun. 1998, 1739-1740. [CrossRef]

37. Beckmann, S.; Etzbach, K.-H.; Krämer, P.; Lukaszuk, K.; Matschiner, R.; Schmidt, A.J.; Schuhmacher, P.; Sens, R.; Seybold, G.; Wortmann, R.; et al. Electrooptical chromophores for nonlinear optical and photorefractive applications. Adv. Mater. 1999, 11, 536-541. [CrossRef]

38. Würthner, F.; Yao, S.; Schilling, J.; Wortmann, R.; Redi-Abshiro, M.; Mecher, E.; Gallego-Gomez, F.; Meerholz, K. ATOP dyes: Optimization of a multifunctional merocyanine chromophore for high refractive index modulation in photorefractive materials. J. Am. Chem. Soc. 2001, 123, 2810-2824. [CrossRef] [PubMed]

39. Kronenberg, N.M.; Deppisch, M.; Würthner, F.; Lademann, H.W.A.; Deing, K.; Meerholz, K. Bulk heterojunction organic solar cells based on merocyanine colorants. Chem. Commun. 2008, 6489-6491. [CrossRef] [PubMed]

40. Gräßler, N.; Wolf, S.; Holzmüller, F.; Zeika, O.; Vandewal, K.; Leo, K. Heteroquinoid merocyanine dyes with high thermal stability as absorber materials in vacuum-processed organic solar cells. Eur. J. Org. Chem. 2019, 31, 845-851. [CrossRef]

41. Bürckstümmer, H.; Kronenberg, N.M.; Gsänger, M.; Stolte, M.; Meerholz, K.; Würthner, F. Tailored merocyanine dyes for solution-processed BHJ solar cells. J. Mater. Chem. 2010, 20, 240-243. [CrossRef]

42. Arjona-Esteban, A.; Lenze, M.R.; Meerholz, K.; Würthner, F. Donor-acceptor dyes for organic photovoltaics. In Elementary Processes in Organic Photovoltaics; Leo, K., Ed.; Springer International Publisher: Cham, Switzerland, 2017; pp. 193-214.

43. Ojala, A.; Petersen, A.; Fuchs, A.; Lovrincic, R.; Pölking, C.; Trollmann, J.; Hwang, J.; Lennartz, C.; Reichelt, H.; Höffken, H.W.; et al. Merocyanine/C60 planar heterojucntion solar cells: Effect of dye orientation on exciton dissociation and solar cell performance. Adv. Funct. Mater. 2012, 22, 86-96. [CrossRef]

44. Shirota, Y.; Kageyama, H. Charge carrier transporting molecular materials and their applications in devices. Chem. Rev. 2007, 107, 953-1010. [CrossRef] [PubMed]

45. Stylianakis, M.M.; Mikroyannidis, J.A.; Dong, Q.; Pei, J.; Tian, W. Synthesis, photophysical and photovoltaic properties of star-shaped molecules with triphenylamine as core and phenylethenylthiophene or dithienylethylene as arms. Sol. Energy Mater. Sol. Cells 2009, 93, 1952-1958. [CrossRef]

46. Yang, Y.; Zhang, J.; Zhou, Y.; Zhao, G.; He, C.; Li, Y.; Andersson, M.; Inganäs, O.; Zhang, F. Solution-processable organic molecule with triphenylamine core and two benzothiadiazole-thiophene arms for photovoltaic application. J. Phys. Chem. C 2010, 114, 3701-3706. [CrossRef]

47. Yasuda, T.; Shinohara, Y.; Matsuda, T.; Han, L.; Ishi-I, T. Improved power conversion efficiency of bulk-heterojunction organic solar cells using a benzothiadiazole-triphenylamine polymer. J. Mater. Chem. 2012, 22, 2539-2544. [CrossRef]

48. Mikroyannidis, J.A.; Stylianakis, M.M.; Suresh, P.; Balraju, P.; Sharma, G.D. Low band gap vinylene compounds with triphenylamine and benzothiadiazole segments for use in photovoltaic cells. Org. Electron. 2009, 10, 1320-1333. [CrossRef] 
49. Xiong, Y.; Wu, B.; Zheng, X.; Zhao, Z.; Deng, P.; Lin, M.; Tang, B.; Ong, B.S. Novel dimethylmethylene-bridged triphenylamine-PDI acceptor for bulk-heterojunction organic solar cells. Adv. Sci. 2017, 4, 1700110. [CrossRef]

50. Ouyang, M.; Wang, G.; Zhang, C. A novel electrochromic polymer containing triphenylamine derivative and pyrrole. Electrochim. Acta 2011, 56, 4645-4649. [CrossRef]

51. Yao, S.; Belfield, K.D. Two-photon fluorescent probes for bioimaging. Eur. J. Org. Chem. 2012, 2012, 3199-3217. [CrossRef]

52. Shirota, Y. Organic materials for electronic and optoelectronic devices. J. Mater. Chem. 2000, 10, 1-25. [CrossRef]

53. Roncali, J. Molecular bulk heterojunctions: An emerging approach to organic solar cells. Acc. Chem. Res. 2009, 42, 1719-1730. [CrossRef] [PubMed]

54. He, C.; He, Q.; Yang, X.; Wu, G.; Yang, C.; Bai, F.; Shuai, Z.; Wang, L.; Li, Y. Synthesis and photovoltaic properties of a solution-processable organic molecule containing triphenylamine and DCM moieties. J. Phys. Chem. C 2007, 111, 8661-8666. [CrossRef]

55. Srivani, D.; Gupta, A.; Bhosale, S.V.; Ohkubo, K.; Bhosale, R.S.; Fukuzumi, S.; Bilic, A.; Jones, L.A.; Bhosale, S.V. A Triphenylamine-naphthalenediimide-fullerene triad: Synthesis, photoinduced charge separation and solution-processable bulk heterojunction solar cells. Asian J. Org. Chem. 2018, 7, 220-226. [CrossRef]

56. Bruce, M.I.; Rodgers, J.R.; Snow, M.R.; Swincer, A.G. Cyclopentadienyl-ruthenium and -osmium chemistry. cleavage of tetracyanoethylene under mild conditions: X-ray crystal structures of $\left[\mathrm{Ru}\left\{\eta^{3}-\mathrm{C}(\mathrm{CN})_{2} \mathrm{CPhC}=\mathrm{C}(\mathrm{CN})_{2}\right\}\left(\mathrm{PPh}_{3}\right)\left(\eta-\mathrm{C}_{5} \mathrm{H}_{5}\right)\right]$ and $\left[\mathrm{Ru}\left\{\mathrm{C}\left[=\mathrm{C}(\mathrm{CN})_{2}\right] \mathrm{CPh}=\mathrm{C}(\mathrm{CN})_{2}\right\}-\left(\mathrm{CNBu}^{\mathrm{t}}\right)\left(\mathrm{PPh}_{3}\right)\left(\eta-\mathrm{C}_{5} \mathrm{H}_{5}\right)\right]$. J. Chem. Soc. Chem. Commun. 1981, 271-272. [CrossRef]

57. Zhou, H.; Yang, L.; You, W. Rational design of high performance conjugated polymers for organic solar cells. Macromolecules 2012, 45, 607-632. [CrossRef]

58. Coughlin, J.E.; Henson, Z.B.; Welch, G.C.; Bazan, G.C. Design and synthesis of molecular donors for solution-processed high-efficiency organic solar cells. Acc. Chem. Res. 2014, 47, 257-270. [CrossRef] [PubMed]

59. Li, Y.; Guo, Q.; Li, Z.; Pei, J.; Tian, W. Solution processable D-A small molecules for bulk-heterojunction solar cells. Energy Environ. Sci. 2010, 3, 1427-1436. [CrossRef]

60. Gao, H.; Li, Y.; Wang, L.; Ji, C.; Wang, Y.; Tian, W.; Yang, X.; Yin, L. High performance asymmetrical push-pull small molecules end-capped with cyanophenyl for solution-processed solar cells. Chem. Commun. 2014, 50, 10251-10254. [CrossRef] [PubMed]

61. Cabau, L.; Pellejà, L.; Clifford, J.N.; Kumar, C.V.; Palomares, E. Light soaking effects on charge recombination and device performance in dye sensitized solar cells based on indoline-cyclopentadithiophene chromophores. J. Mater. Chem. A 2013, 1, 8994-9000. [CrossRef]

62. Ma, X.; Azeem, E.A.; Liu, X.; Cheng, Y.; Zhu, C. Synthesis and tunable chiroptical properties of chiral BODIPY-based D- $\pi-A$ conjugated polymers. J. Mater. Chem. C 2014, 2, 1076-1084. [CrossRef]

63. Zhao, T.; Liu, Z.; Song, Y.; Xu, W.; Zhang, D.; Zhu, D. Novel diethynylcarbazole macrocycles: synthesis and optoelectronic properties. J. Org. Chem. 2006, 71, 7422-7432. [CrossRef] [PubMed]

64. Suraru, S.-L.; Würthner, F. Regioselectivity in sequential nucleophilic substitution of tetrabromonaphthalene diimides. J. Org. Chem. 2013, 78, 5227-5238. [CrossRef]

65. Frisch, M.J.; Trucks, G.W.; Schlegel, H.B.; Scuseria, G.E.; Robb, M.A.; Cheeseman, J.R.; Scalmani, G.; Barone, V.; Petersson, G.A.; Nakatsuji, H.; et al. Gaussian 09, Revision C.01; Gaussian Inc.: Wallingford, CT, USA, 2009.

66. Avogadro: An Open-Source Molecular Builder and Visualization Tool, Version 1.1.0. Available online: http:/ / avogadro.openmolecules.net/ (accessed on 31 March 2019).

67. Hanwell, M.D.; Curtis, D.E.; Lonie, D.C.; Vandermeersch, T.; Zurek, E.; Hutchison, G.R. Avogadro: An advanced semantic chemical editor, visualization and analysis platform. J. Cheminform. 2012, 4, 17. [CrossRef] [PubMed]

68. Cardona, C.M.; Li, W.; Kaifer, A.E.; Stockdale, D.; Bazan, G.C. Electrochemical considerations for determining absolute frontier orbital energy levels of conjugated polymers for solar cell applications. Adv. Mater. 2011, 23, 2367-2371. [CrossRef] [PubMed]

(C) 2019 by the authors. Licensee MDPI, Basel, Switzerland. This article is an open access article distributed under the terms and conditions of the Creative Commons Attribution (CC BY) license (http://creativecommons.org/licenses/by/4.0/). 